This is the final peer-reviewed accepted manuscript of:

P. Magnone, M. Debucquoy, D. Giaffreda, N. Posthuma and C. Fiegna

"Understanding the Influence of Busbars in Large-Area IBC Solar Cells by Distributed SPICE Simulations," in IEEE Journal of Photovoltaics, vol. 5, no. 2, pp. 552-558, March 2015.

The final published version is available online at:

https://doi.org/10.1109/JPHOTOV.2015.2392939

Rights / License:

The terms and conditions for the reuse of this version of the manuscript are specified in the publishing policy. For all terms of use and more information see the publisher's website.

This item was downloaded from IRIS Università di Bologna (https://cris.unibo.it/)

When citing, please refer to the published version. 


\title{
Understanding the Influence of Busbars in Large-Area IBC Solar Cells by Distributed SPICE Simulations
}

\author{
Paolo Magnone, Maarten Debucquoy, Daniele Giaffreda, Niels Posthuma, Claudio Fiegna
}

\begin{abstract}
In this paper we model a large-area high-efficiency interdigitated back-contact (IBC) solar cell by means of a distributed electrical network. The simulation tool allows accounting for the distributed resistive effects in diffusions and metallization. The model also considers the electrical shading effect and resistive losses due to both $\mathrm{BSF}$ and emitter busbars. A calibrated model is used to investigate the case of a large-area $\left(15.6 \times 15.6 \mathrm{~cm}^{2}\right)$ IBC cell, in which we investigate the influence of key busbar parameters: number of busbars; busbar width; soldering pitch (for module connection); metal sheet resistance. The predictive simulations allow finding out the optimum number of busbars, arising from a tradeoff between the electrical shading effect due to the BSF busbars and resistive losses due to the emitter busbars and the fingers. Moreover, we show how the distance between soldering points on the metal busbars, influences the choice of the busbar width. We found out that, if an adequate number $(>7)$ of soldering points is adopted, the busbar width should be kept lower than $0.5 \mathrm{~mm}$. On the other hand, the adoption of a thick Cu-plating $(15 \mu \mathrm{m})$ leads to an increase of efficiency of $0.2 \%$ abs with respect to the case of sputtered Al metal ( $3 \mu \mathrm{m}$ thick).
\end{abstract}

Index Terms - interdigitated back-contact (IBC), solar cell, distributed model, simulations, electrical shading, SPICE, photovoltaic, busbar.

\section{INTRODUCTION}

Interdigitated back-contact (IBC) solar cells are part of the current research activities of the PV community and conversion efficiency higher than $24 \%$ have been reported [16]. However, there are several challenges related to the backcontact solar cell design, which should be addressed. Electrical shading effect is the result of a reduced minority charge carrier collection probability in the BSF and generally in a non-diffused gap region, due to an increased recombination $[7,8]$. This leads to a reduction of the shortcircuit current density $\left(J_{S C}\right)$. In contrast, in emitter regions holes are collected (assuming n-type substrate), but electrons

Manuscript received August 1, 2014.

P. Magnone is with DTG, University of Padova, Stradella S. Nicola 3, I36100 Vicenza, Italy (e-mail: paolo.magnone@unipd.it).

D. Giaffreda and C. Fiegna are with ARCES and DEI "Gugliemo Marconi", University of Bologna and IUNET, Via Venezia 260, I-47521 Cesena (FC), Italy (e-mail: dgiaffreda@arces.unibo.it, claudio.fiegna@ unibo.it).

M. Debucquoy and N. Posthuma are with IMEC, Kapeldreef 75, B-3001 Heverlee, Belgium (e-mail: Maarten.Debucquoy@imec.be, Niels.Posthuma@imec.be). need to be transported laterally to BSF regions. This lateral transport adds resistive losses and hence leads to fill factor (FF) reduction [9]. This behavior of BSF and emitter regions becomes critical when designing the busbar regions.

In order to achieve large-area IBC solar cells $(15.6$ x 15.6 $\mathrm{cm}^{2}$ ), an increased number of busbars can be considered to limit resistive losses related to current transport over the long fingers. As each BSF and emitter busbar adds a loss in $J_{S C}$ or $F F$, a trade-off is required between the losses introduced by the busbars and the losses introduced by the long fingers. Hence, in order to reach an efficient cell design, a modelling environment is essential.

TCAD device simulations of IBC solar cells have been adopted in order to analyze doping profiles, passivation schemes and recombination mechanisms [10-13]. However, due to the computational effort, the simulation domain is typically limited to a small element of symmetry, which does not account for finger and busbar effects. On the other hand, recently, different authors have shown modelling activities for solar cells, by simulating distributed electrical models [14-16]. In [15], two different IBC cell types (with broken and full line contact openings) are investigated by mixing experimental results and electrical simulations performed with a distributed model. However, the effect of busbars is not accounted for. In [16], a distributed network is used to discuss different contacting schemes for IBC solar cells with four busbars and evaluate their impact on the fill factor evaluation. In [17], an IBC version of a Quokka model is presented, allowing for fast simulations by means of finite volume implementation in MATLAB. The influence of perimeter losses in IBC solar is reported, including the effect of busbars. However, the analysis is limited to the case of small solar cells $\left(16 \mathrm{~cm}^{2}\right)$ having two busbars only.

In [18], we presented a quasi 3-D distributed electrical model for IBC solar cells, which is able to account the influence of BSF and emitter busbars. The validity of the model was verified by means of comparison with experimental measurements in the case of a small area $\left(4 \mathrm{~cm}^{2}\right)$ IBC solar cell with two busbars. With respect to [15-18], we perform a comprehensive study allowing us to investigate large-area $\left(15.6 \times 15.6 \mathrm{~cm}^{2}\right)$ IBC solar cell with multiple busbars. Moreover, the influence of important geometrical and electrical properties of the busbars (number, width, soldering pitch, metal sheet resistance) is analyzed. Useful information 


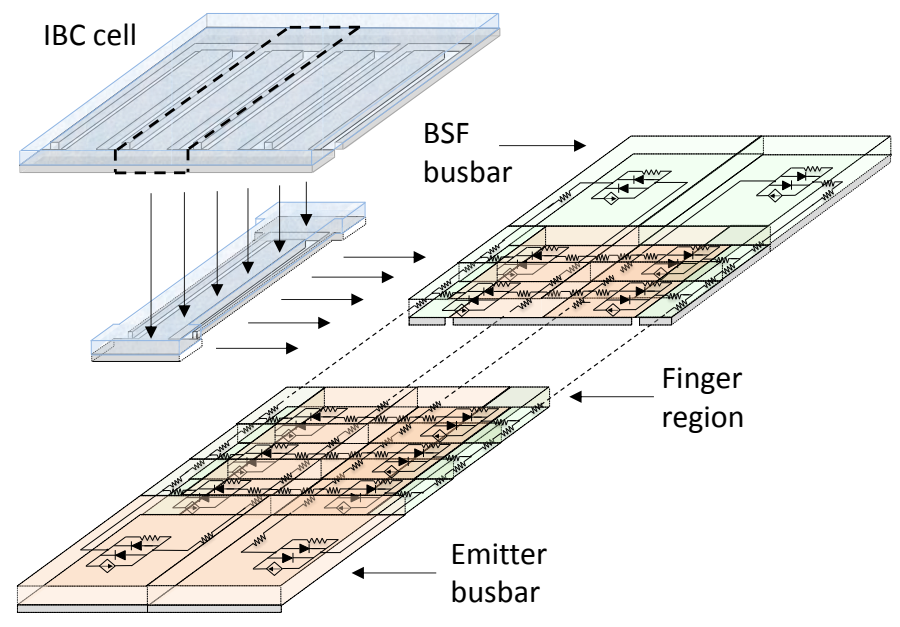

Fig. 1. Schematic representation of an IBC solar cell with the proposed model. Elementary units, which are based on the two-diodes circuits, are implemented in the distributed electrical network.

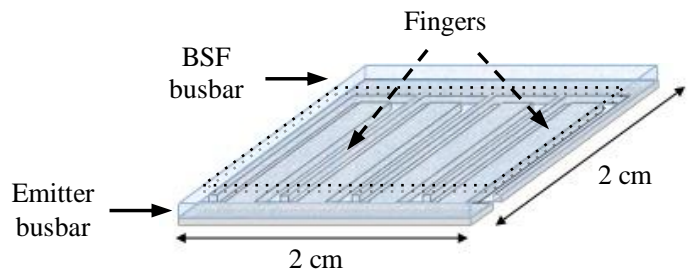

be

Fig. 2. Schematic of the experimental IBC solar cell [18]. The black dashed line indicates the cell area without considering the two busbars.

about the optimal grid configuration can derived, allowing to provide guidelines for the development of large area IBC solar cells.

The paper is organized as follows. In section II we review the distributed electrical model along with its experimental calibration and validation on a small area IBC silicon solar cell and we analyze the influence of busbar width. In section III we adopt the model to simulate a large-area IBC solar cell and to evaluate the impact of geometrical and electrical configuration. Finally, conclusive remarks are provided in section IV.

\section{II.DISTRIBUTED ELECTRICAL MODEL}

\section{A. Description of the Model}

In IBC solar cells the $p-n$ junction is placed on the rear side. Moreover, the emitter and BSF regions are designed in an interdigitated pattern. We model the electric behavior of the solar cell, by dividing the whole cell area into smaller subcircuits and solving the resulting network with a SPICE circuit simulator. In Fig. 1 we report a schematic representation of the equivalent circuit network in which three main regions can be recognized: finger region, containing the interdigitated structure; emitter busbar region; BSF busbar region. The elementary unit, representative of the finger region, is composed by a 2-diode model in which the current source $J_{P H O}$ represents the photogenerated current and is proportional to the irradiance, while the diode saturation current densities $J_{01}$ and $J_{02}$, account for the recombination mechanisms. The model also includes the following resistive components: shunt
TABLE I

MAIN ELECTRICAL AND GEOMETRICAL PARAMETERS ADOPTED FOR THE CALIBRATION OF THE SMALL-AREA IBC CELL.

\begin{tabular}{|l|c|}
\hline Description & Value \\
\hline Emitter sheet resistance & $80 \Omega / \square$ \\
\hline BSF sheet resistance & $50 \Omega / \square$ \\
\hline Bulk sheet resistance & $120 \Omega / \square$ \\
\hline Resistivity of metallization & $2.7 \cdot 10^{-6} \Omega \mathrm{cm}$ \\
\hline Specific contact resistance & $1 \cdot 10^{-4} \Omega \mathrm{cm}^{2}$ \\
\hline Metal thickness & $2 \mu \mathrm{m}$ \\
\hline Busbar width & $1900 \mu \mathrm{m}$ \\
\hline
\end{tabular}

resistance $R_{S H}$; 2-dimensional resistive network due to the conduction through emitter region $\left(R_{E}\right)$ and BSF region $\left(R_{B S F}\right)$; contact resistance at metal/emitter $\left(R_{C E}\right)$ and metal/BSF $\left(R_{B S F}\right)$; distributed resistances associated to the metallization of the emitter $\left(R_{M E}\right)$ and BSF $\left(R_{M B S F}\right)$ fingers.

The elementary unit representing the BSF busbar region, is also composed of a 2-diode model and of a metal and BSF resistive network. Because of the electrical shading effect, above the BSF busbar area a lower collection probability of the photogenerated minority carriers is found with respect to the finger region. This is because the bulk diffusion length becomes comparable or lower than the minority carrier paths, that is the distance from the $p n$-junction. As a matter of fact, a reduction of the short-circuit current is observed when the BSF busbar area is illuminated. In order to calculate the photogenerated current in the BSF busbar region, let us consider the generic decay of excess holes with distance [19]:

$$
p_{n}(x)=p_{n 0}+\left[p_{n e}-p_{n 0}\right] e^{-x / D_{\text {lenglh }}}
$$

where $D_{\text {length }}$ is effective diffusion length in the BSF busbar region, $p_{n e}$ is the injected hole concentration and $\mathrm{x}$ is the distance. Since we are interested in the concentration at the pn junction, $x$ can be considered as the distance from the edge of the busbar. Holes are uniformly generated in the BSF busbar area and the current collected at the pn junction can be calculated as the integral of the photogenerated rate $d p_{n} / d t$ from $x=0$ to $x=W_{B S F B B}$ (BSF busbar width):

$$
\begin{aligned}
& I_{P H, B S F B B}=W_{\text {cell }} \cdot t_{s} \cdot q \cdot \int_{0}^{W_{B S B B B}}\left(\frac{d p_{n}(x)}{d t}\right) d x= \\
& =W_{\text {cell }} \cdot t_{s} \cdot q \frac{d p_{n e}}{d t} \cdot \alpha \cdot W_{B S F B B}\left(1-e^{-\frac{1}{\alpha}}\right)
\end{aligned}
$$

where $\alpha=D_{\text {length }} / W_{B S F B B}, W_{\text {cell }}$ and $t_{s}$ are the width and thickness of the cell, respectively, $q$ is the elementary charge. The quantity $t_{s} \cdot q \cdot d p_{n e} / d t$ represents the photogerated current $\left(J_{P H O}\right)$, which must account for other recombination effects (e.g. surface recombination) except for the shading effect. The current source of the model, for a generic elementary unit $(i, j)$ can be calculated as:

$$
I_{P H, B S F B B}(i, j)=A_{U}(i, j) \cdot J_{P H 0}(i, j) \cdot G / G_{0} \cdot \alpha \cdot\left(1-e^{-\frac{1}{\alpha}}\right)
$$

where $A_{u}(i, j)$ is the area of the considered $(i, j)$ cell, $G_{0}$ is the 


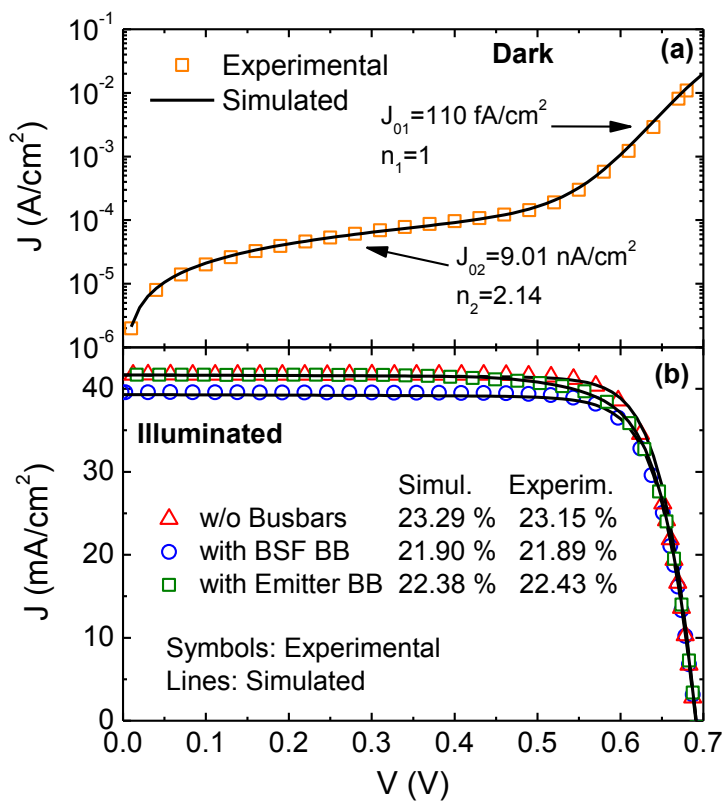

Fig. 3. Dark (a) and Illuminated (b) JV curves. Simulation results are in agreement with experimental data. In (b) different shading conditions are considered for the emitter and BSF busbars in order to verify the accuracy of the model [18].

irradiance at 1 sun, $G$ is the considered irradiance (which can be equal to 0 in case of shaded busbar or dark conditions). Once the $D_{\text {length }}$ is calibrated, the distributed electrical model is able to account for the influence of busbar width on the shortcircuit current. In the BSF busbar region there is no contact between the metal layer and the substrate. The assumption of non-contacted busbar is in agreement with the experimental IBC cell considered in this work for the model calibration.

The emitter busbar elementary unit does not show reduced collection probability of holes, because of the emitter region (and hence of the pn-junction) above the busbar. However, electrons photogenerated in this region, have to drift though the (highly resistive) bulk region towards the finger region. This leads to a significant increase of resistive losses and hence to a reduction of the fill factor.

The element of symmetry, to be simulated, is delimited by the soldering pitch on the busbars and by the distance between busbar centers. With reference to Fig. 1, the elementary units have a length of $100 \mu \mathrm{m}$ along the finger direction and a width of $767 \mu \mathrm{m}$ equal to half of the finger pitch. The computational time is then function of the considered element of symmetry and, in a state-of-the-art desktop PC, one IV curve simulation can last from a few minutes up to a few hours.

\section{B. Calibration of the Simulation Tool}

The accuracy of the model was verified in [18] by means of comparison with experimental data. The IBC sample considered was an $n$-type silicon solar cell with a finger region of $2 \times 2 \mathrm{~cm}^{2}$ and two busbars at the opposite sides of the cell [20]. A schematic of the IBC cell is reported in Fig. 2, while in Table I we report the main electrical and geometrical properties used for the calculation of resistive network.

As a first step, dark JV measurements are used in order to calculate $J_{01}$ and $J_{02}$ saturation current densities and the shunt

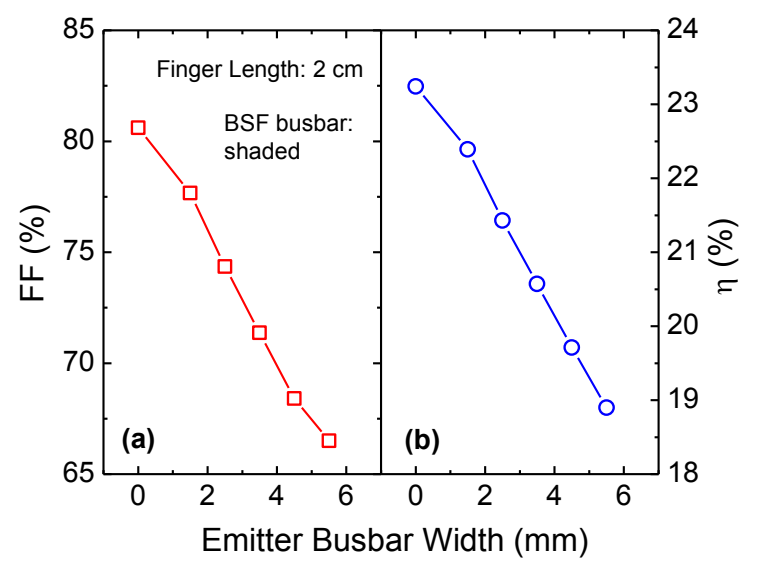

Fig. 4. Simulated (a) fill factor and (b) efficiency of an IBC cell as a function of the emitter busbar width. Due to the increase of resistive losses, because of the conduction above the emitter busbar region, a reduction of $F F$ is observed with the busbar width.

resistance and the comparison with simulation is reported in Fig. 3a. The effect of non-ideal ideal recombination is accounted for in the $J_{02}$ component.

As a second step, experimental JV curves under AM1.5G spectrum are considered, aiming at calibrating $J_{P H O}$. In order to avoid the $J_{S C}$ and $F F$ reduction due to the emitter and BSF busbars, a mask was adopted to illuminate the finger region only. The accuracy of the model is also verified by considering the impact of busbars on the figures of merit of the cell. The results are reported in Fig. 3b. In particular we considered three different cases: i) JV curve with both busbars shaded (red triangles); ii) JV curve with BSF busbar illuminated and emitter busbar shaded (blue circles); iii) JV curve with emitter busbar illuminated and BSF busbar shaded (green squares). In all the three cases, we found out a good agreement between experimental data and simulation results. As expected the highest efficiency is obtained when both busbars are shaded. On the other hand, when considering an illuminated BSF busbar, the experimental efficiency drop due to the electrical shading is well modeled by the electrical simulations. Moreover, if the IBC cell with illuminated emitter busbar is measured, a $F F$ reduction is observed. This FF degradation can be ascribed to resistive losses and hence can be modeled with the conduction through the bulk region.

\section{Impact of Busbar Regions}

In order to investigate the influence of the busbar regions on the solar cell performance, we used the calibrated model to simulate an IBC cell with different emitter and BSF busbar widths. In particular, we considered a constant finger length of $2 \mathrm{~cm}$ while varying the busbar width up to $5.5 \mathrm{~mm}$.

In Fig. 4 we report $F F$ and $\eta$ as a function of the emitter busbar width. In this case, the BSF busbar area is considered shaded. Due to electrons drifting through the bulk region above the emitter busbar, the increase of busbar width leads to a significant reduction of $F F$ and hence of efficiency. In particular, a $F F$ as low as $66 \%$ is found if a busbar width of $5.5 \mathrm{~mm}$ is considered. In Fig. 5 we analyze the impact of BSF busbar width on $J_{S C}$ and $\eta$. Because of the electrical shading effect, a strong reduction of $J_{S C}$, and consequently of $\eta$, is 


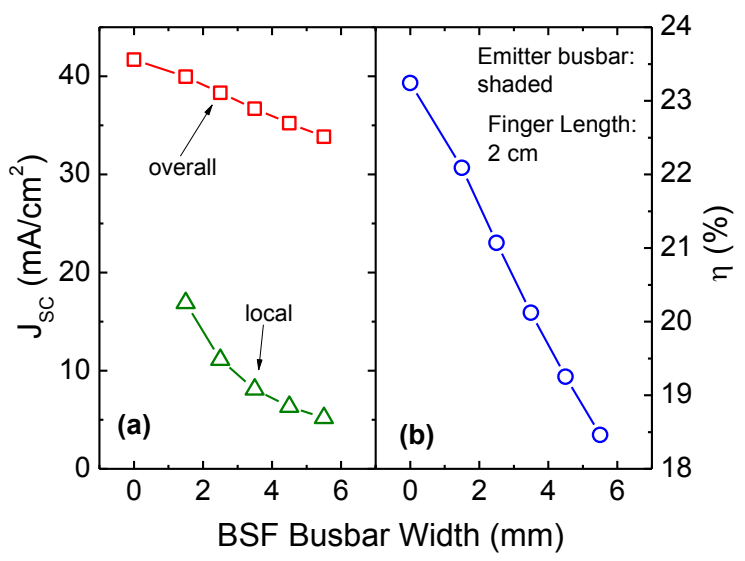

Fig. 5. Simulated (a) short-circuit current and (b) efficiency as a function of the BSF busbar width. By increasing the busbar width, the short-circuit current decreases because of the electrical shading.

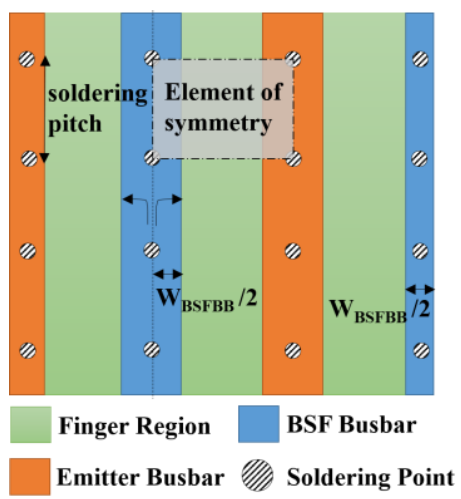

Fig. 6. Schematic of busbars geometry and soldering points in the case of IBC solar cell featuring lateral busbars with half width with respect to inner busbars.

observed when increasing the busbar width. Besides the increase of percentage area covered by BSF busbar, the overall $J_{S C}$ reduction must be also ascribed to the local $J_{S C}$ degradation in the BSF busbar area (see Fig. 5a). These findings are in agreement with what reported in [7].

\section{Simulation of Large-Area IBC Solar Cell}

In the case of unequal currents per busbar, as for IBC solar cell, the contacting scheme can significantly affect the FF of the cell [21]. In this paper, we consider voltage (and current) probes placed at each soldering point. According to Fig. 6, a resulting soldering pitch can be defined. We assume the cable resistance and the soldering (or pin) contact resistance to be negligible, hence, all voltage (and current) probes are assumed be short-circuited with no resistance. Therefore, we will consider ideal FF, which does not account for losses due to the contacting scheme.

As shown in Fig. 6, the lateral busbars are assumed to have half width with respect to inner busbars. This ensures a uniform voltage drop between lateral and inner busbars. It is worth noting that, the assumption of half lateral busbar could be subject to manufacturing constraints.

The experimental IBC cell considered in section II has a limited area of $2 \times 2 \mathrm{~cm}^{2}$. In order to extend the cell to a conventional area of $15.6 \times 15.6 \mathrm{~cm}^{2}$, it is important to properly investigate the geometry of busbars. In this section,
TABLE II

PARAMETERS CONSIDERED FOR THE ANALYSIS OF THE LARGE-AREA IBC CELL

\begin{tabular}{|l|c|}
\hline Description & Value \\
\hline Metallization & $\mathrm{Cu} 5 \mu \mathrm{m}$ thick; $\mathrm{Cu} 15 \mu \mathrm{m}$ thick; \\
& $\mathrm{Al} 3 \mu \mathrm{m}$ thick; \\
\hline Busbar width & from $0.3 \mathrm{~mm}$ up to $1 \mathrm{~mm}$ \\
\hline Soldering pitch & from $0.1534 \mathrm{~cm}$ up to $3.835 \mathrm{~cm}$ \\
\hline Emitter finger width & $1044 \mu \mathrm{m}$ \\
\hline BSF finger width & $330 \mu \mathrm{m}$ \\
\hline
\end{tabular}

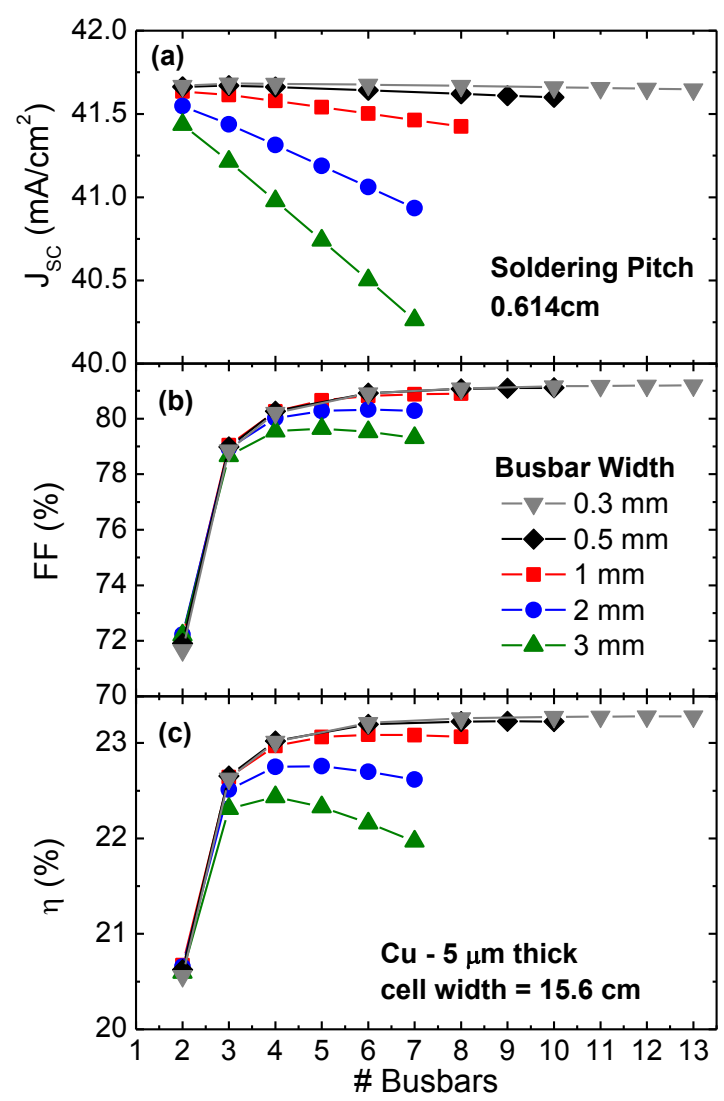

Fig. 7. Simulated (a) short-circuit current, (b) fill factor and (c) efficiency of a $15.6 \mathrm{~cm}$ wide IBC cell as a function of number of busbars.

the distributed model is adopted to simulate a $15.6 \mathrm{~cm}$ wide IBC solar cell, in which the number of busbars, the busbar width, the soldering pitch and the metal sheet resistance are used as parameters. Table II summarizes the main parameters considered in section III for the simulation of large-area IBC solar cell.

\section{A. Influence of Number of Busbars}

In this subsection, the soldering pitch is considered to be $0.614 \mathrm{~cm}$. This value is chosen small enough to neglect the voltage drop along busbars, since the influence of the soldering pitch is investigated in subsection III.B. We consider $\mathrm{a} \mathrm{Cu}$ metallization having a thickness of $5 \mu \mathrm{m}$ and a busbar width ranging from $0.3 \mathrm{~mm}$ up to $3 \mathrm{~mm}$. The number of busbars is varied in order to find optimum value of efficiency.

The short-circuit current (Fig. 7a) reduces by increasing the number and the width of busbars, because of the electrical shading effect due to the BSF busbar. In case of wide busbars, the $J_{S C}$ degradation is larger.

The fill factor behavior, reported in Fig. 7b, is the result of two competing effects. In fact, the finger resistance reduces by 


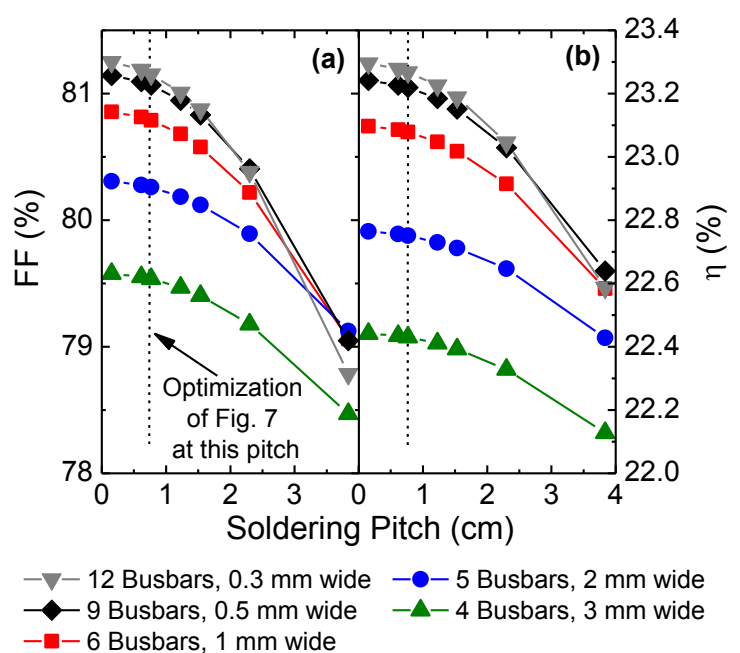

Fig. 8. Simulated (a) fill factor and (b) efficiency of a $15.6 \mathrm{~cm}$ wide IBC cell as a function of soldering pitch (for module connection). $\mathrm{Cu}$ metallization, 5 $\mu \mathrm{m}$ thick, is considered.

increasing the number of busbars, and this explain the initial increase of $F F$. On the other hand, the $F F$ losses due to conduction above the emitter busbar increase as long as the considered number of busbars is increased. As discussed in section II, the last effect is minimized in the case of narrow busbars, hence leading to higher $F F$.

According to the considered busbar width, an optimum number of busbars can be observed in Fig. 7c, allowing to maximize the conversion efficiency in a large-area IBC solar cell. This results from the trade-off between $J_{S C}$ degradation due to the electrical shading effect and the $F F$ reduction due to the finger resistance and the conduction above the emitter busbars. The narrowing of the busbars, leads to an improvement of both $J_{S C}$ and $F F$, as reported in Fig. 7a and Fig. 7b, respectively. However, for a busbar width lower than $0.5 \mathrm{~mm}$, no improvements of $F F$ are observed, meaning that the resistive losses due to the emitter busbars are negligible. As a matter of fact, the $F F$ tends to saturate for a large number of busbars, rather than having a bell shape. Moreover, only a small increase of $J_{S C}$ is observed. In general, the narrower are the busbars, the larger is the number of busbars allowing to maximize the efficiency. The best performance are achieved in the case of $0.3 \mathrm{~mm}$ wide busbars, featuring a maximum conversion efficiency higher than $23.2 \%$.

\section{B. Analysis of Soldering Pitch}

In subsection III.A, the soldering pitch was fixed to a relatively small value of $0.614 \mathrm{~cm}$. This would mean 25 soldering points on one busbar of $15.6 \mathrm{~cm}$ long. For this value, the conduction through metal busbars is not limitative. However, especially in the case of narrow busbars, $F F$ could be strongly affected by the soldering pitch. Hence, in order to further investigate the influence of BSF and emitter metal busbars, in Fig. 8 we report the $F F$ and efficiency as a function of the soldering pitch and of the busbar width. The number of busbars is chosen accordingly to the optimum values derived in Fig. 7. Narrow busbars lead to a larger degradation of $F F$. For a soldering pitch of $0.614 \mathrm{~cm}$ (as

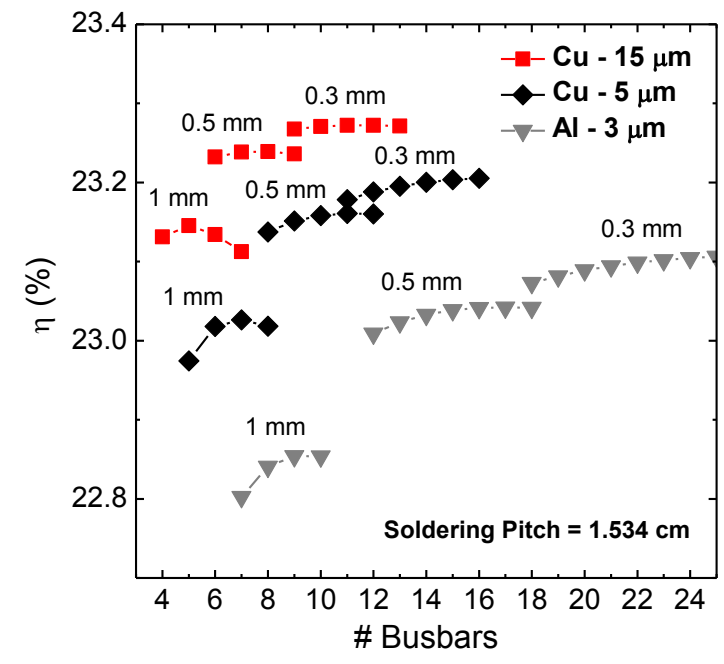

Fig. 9. Simulated efficiency of a $15.6 \mathrm{~cm}$ wide IBC cell with a soldering pitch of $1.534 \mu \mathrm{m}$. The co-optimization of busbar witdth and number of busbars is performed for different types of metallization: $\mathrm{Cu} 15 \mu \mathrm{m}$ thick, $\mathrm{Cu} 5 \mu \mathrm{m}$ thick and Al $3 \mu \mathrm{m}$ thick. The considered busbar width $(0.3 \mathrm{~mm}, 0.5 \mathrm{~mm}, 1 \mathrm{~mm})$ is reported in the figure.

considered in Fig. 7), the $F F$ losses are small for all the considered busbar width. However, a small soldering pitch and consequently a large number of soldering points, can lead to an increased cost to assemble the IBC cells into a module [22]. If we consider a pitch as a large as $3.8 \mathrm{~cm}$, we observe a maximum $F F$ reduction of about $2.3 \%$ abs in the case of 0.3 $\mathrm{mm}$ wide busbars. As a result, the optimum busbar width is function of the soldering pitch. The simulation results of this paper indicate that, if a $5 \mu \mathrm{m}$ thick $\mathrm{Cu}$ metallization is adopted, the optimum busbar width is in the range $0.3 \mathrm{~mm}-$ $0.5 \mathrm{~mm}$, depending on the considered soldering pitch.

It is worth noting that, the soldering points can have a width of a few millimeters, hence larger than the busbar width. This effect is not accounted for in our simulations and can potentially lead to a degradation of efficiency, especially in the case of narrow busbars with a lot of soldering points.

\section{Impact of Metal Sheet Resistance}

The co-optimization of the number of busbars and busbar width, reported in section III.A, leads to a trade-off between finger metal losses, electrical shading due to BSF busbar and resistive losses above the emitter busbar. Moreover, the presence of soldering points on metal busbars, as discussed in section III.B, leads to resistive losses along metal busbars. Hence, metal sheet resistance is a crucial parameter for the cooptimization process. Therefore, in this section we compare three types of metallization: Al $3 \mu \mathrm{m}$ thick; $\mathrm{Cu} 5 \mu \mathrm{m}$ thick; $\mathrm{Cu}$ $15 \mu \mathrm{m}$ thick. The simulated efficiency is reported in Fig. 9, where the busbar width is considered equal to $0.3 \mathrm{~mm}, 0.5 \mathrm{~mm}$ or $1 \mathrm{~mm}$, while the soldering pitch is kept constant to 1.534 $\mathrm{cm}$.

The optimum value of efficiency is achieved in the case of $0.3 \mathrm{~mm}$ wide busbars, meaning that the conduction through the metal busbars is not limitative for the considered soldering pitch. As expected, the simulation results indicate that the adoption of Cu-plating (15 $\mu \mathrm{m}$ thick) leads to the best performance. From one hand, the advantage over the sputtered $\mathrm{Al}$ metal is limited to about $0.2 \%$ abs. On the other hand, in the 
case of thick $\mathrm{Cu}$ busbar, the optimum efficiency is achieved for a significantly lower number of busbars. In turn, a lower total number of soldering points is required. Interestingly, the wider busbars $(1 \mathrm{~mm})$ lead to a higher increase of efficiency (from $\mathrm{Al} 3 \mu \mathrm{m}$ thick to $\mathrm{Cu} 15 \mu \mathrm{m}$ thick), of about $0.3 \%$ abs. As reported in Fig. $7 \mathrm{~b}$, the $F F$ of $0.5 \mathrm{~mm}$ or $0.3 \mathrm{~mm}$ wide busbars does not decrease when the number of busbars is increased. Hence, in the case of poor metal conductivity the number of busbars can be effectively increased to limit the resistive losses along the metal busbars and metal fingers. Otherwise, in the case of $1 \mathrm{~mm}$ wide (or wider) busbars, the increase of the number of busbars leads to a reduction of $F F$, because of the conduction above the emitter busbars. Overall, when a low metal sheet resistance is considered, a better tradeoff is achieved in the case of narrow busbars.

\section{CONCLUSIONS}

In this work, we analyzed the influence of BSF and emitter busbars in large-area $(15.6 \mathrm{~cm}$ wide) IBC solar cells by means of a calibrated SPICE simulation tool.

The optimum number of busbars arises from a trade-off between on one side the $J_{S C}$ degradation due to the electrical shading effect above the BSF busbars and the $F F$ reduction due to the conduction above the emitter busbars, and on the other side the metal finger resistance.

We also investigated the influence of soldering pitch on the metal busbars, which is an important parameter to be considered for connections at module level. This introduces an additional trade-off in the width of the busbars: the metal busbars need to be wide enough to limit resistive losses towards the soldering points. In the case of $0.3 \mathrm{~mm}$ wide busbar ( $\mathrm{Cu} 5 \mu \mathrm{m}$ thick), a soldering pitch of $3.8 \mathrm{~cm}$ leads to a $F F$ and efficiency degradation (with respect to a soldering pitch of $0.15 \mathrm{~cm}$ ) of $2.3 \%$ abs and $0.7 \%$ abs, respectively. Then, a busbar width lower than $0.5 \mathrm{~mm}$ can be adopted to maximize the efficiency, provided that an adequate number (>7) of soldering points is implemented. Moreover, if we consider a thick Cu-plating $(15 \mu \mathrm{m})$, an increase of efficiency of about $0.2 \%_{\text {abs }}$ is observed compared to the case of sputtered $\mathrm{Al}$ metal (3 $\mu$ m thick).

In the case of low conductive metal (thin $\mathrm{Al}$ ) a lot of thin busbars are required to limit resistive losses over the metal fingers. If we consider high conductive metal (thick $\mathrm{Cu}$ ), longer fingers can be used and hence there is less need to keep busbars narrow.

Overall, this paper provides useful guidelines for the busbar design in large-area IBC solar cell, allowing to exceed $23 \%$ of efficiency.

\section{REFERENCES}

[1] C. M. Garner, R. D. Nasby and F. Sexton, «An interdigitated back contact solar cell with high-current collection,» IEEE Electron Device Lett., vol. 1, n. 12, pp. 256-258, 1980.

[2] P. J. Cousins, D. D. Smith, L. Hsin-Chiao, J. Manning, T. D. Dennis, A. Waldhauer, K. E. Wilson, G. Harley and W. P. Mulligan, «Generation 3: Improved performance at lower cost,» in Proc. 35th IEEE Photovoltaic Specialist Conference PVSC, Honolulu, Hawaii, US, 2010.

[3] M. Aleman, J. Das, T. Janssens, B. Pawlak, N. Posthuma, J. Robbelein, S. Singh, K. Baert, J. Poortmans, J. Fernandez, K. Yoshikawa and P. J. Verlinden, «Development and Integration of a High Efficiency Baseline
Leading to 23\% IBC Cells,» Energy Procedia, vol. 27, pp. 638-645, 2012.

[4] K. Fong, K. Teng, K. McIntosh, A. Blakers, E. Franklin, S. Ngwe and F. A., «Optimisation of N+ Diffusion and Contact Size of IBC Solar Cells,» in Proceedings of the 28th European Photovoltaic Solar Energy Conference and Exhibition, Paris, France, 2013.

[5] N. Harder, P. Altermatt, A. Cuevas and G. Heiser, «Numerical modelling of rear junction si solar cells using fermi-dirac statistics,» in Proceedings of the 19th European Photovoltaic Solar Energy Conference and Exhibition, Paris, France, 2004.

[6] E. Van Kerschaver and G. Beaucarne, «Back-contact Solar Cells: A Review,» Prog. Photovoltaics, vol. 14, n. 2, pp. 107-123, 2006.

[7] M. Hermle, F. Granek, O. Schultz-Wittmann and S. Glunz, «Shading effects in Back-Junction Back-contacted silicon solar cells,» in Proc. 33rd IEEE Photovoltaic Specialist Conference PVSC, St. Diego, CA, USA, 2008.

[8] C. Reichel, F. Granek, M. Hermle and S. W. Glunz, «Investigation of electrical shading effects in back-contacted back-junction silicon solar cells using the two-dimensional charge collection probability and the reciprocity theorem,» J. Appl. Phys., vol. 109, 2011.

[9] F. Granek, M. Herml, D. M. Huljić, O. Schultz-Wittmann and S. W. Glunz, «Enhanced lateral current transport via the front $\mathrm{N}+$ diffused layer of n-type high-efficiency back-junction back-contact silicon solar cells,» Prog. Photovoltaics, vol. 17, n. 1, pp. 47-56, 2009.

[10] O. Nichiporuk, A. Kaminski, M. Lemiti, A. Fave and V. Skryshevsky, «Optimisation of interdigitated back contacts solar cells by twodimensional,» Sol. Energ. Mat. Sol. Cells, vol. 86, n. 4, pp. 517-526, 2005.

[11] J. Renshaw and A. Rohatgi, «Device optimization for screen printed interdigitated back contact solar cells,» in Proc. of 37th IEEE Photovoltaic Specialists Conference (PVSC), Seattle, WA, US, 2011.

[12] P. Procel, V. Maccaronio, F. Crupi, G. Cocorullo, M. Zanuccoli, P. Magnone and C. Fiegna, «Analysis of the impact of doping levels on performance of back contact - back junction solar cells,» Energy Procedia, 2014.

[13] S. Kluska, F. Granek, M. Rüdiger, M. Hermle and S. W. Glunz, «Modeling and optimization study of industrial n-type high-efficiency back-contact back-junction silicon solar cells,» Sol. Energ. Mat. Sol. Cells, vol. 94, n. 3, pp. 568-577, 2010.

[14] D. Giaffreda, P. Magnone, M. Meneghini, M. Barbato, G. Meneghesso, E. Zanoni, E. Sangiorgi and C. Fiegna, «Local Shunting in Multicrystalline Silicon Solar Cells: Distributed Electrical Simulations and Experiments,» IEEE J. Photovoltaics, vol. 4, n. 1, pp. 40-47, 2014.

[15] F. Haase, S. Eidelloth, R. Horbelt, K. Bothe, E. Garralaga Rojas and R. Brendel, «Loss analysis of back-contact back-junction thin-film monocrystalline silicon solar cell,» J. Appl. Phys., vol. 10, n. 12, 2011.

[16] C. Schinke, F. Kiefer, M. Offer, D. Hinken, A. Schmidt, N.-P. Harder and R. Bock, «Contacting Interdigitated Back-Contact Solar Cells With Four Busbars for Precise Current-Voltage Measurements Under Standard Testing Conditions,» IEEE J. Photovoltaics, vol. 2, n. 3, pp. 247-255, 2012.

[17] A. Fell, K. C. Fong, K. R. McIntosh, E. Franklin and A. W. Blakers, «3D Simulation of Interdigitated-Back-Contact Silicon Solar Cells With Quokka Including Perimeter Losses,» IEEE Journal of Photovoltaics, vol. 4, n. 4, pp. 1040-1045, 2014.

[18] D. Giaffreda, M. Debucquoy, P. Magnone, N. Posthuma and C. Fiegna, «A distributed electrical model for interdigitated back contact silicon solar cells,» Energy Procedia, vol. 55, pp. 71-76, 2014.

[19] S. M. Sze and K. K. Ng, Physics of Semiconductor Devices, Wiley, 2007.

[20] B. J. O’Sullivan, M. Debucquoy, S. Singh, A. Uruena De Castro, M. Recaman Payo, N. E. Posthuma, I. Gordon, J. Szlufcik and J. Poortmans., «Process Simplification for High Efficiency, Small Area Interdigitated Back Contact Silicon Solar Cells,» in 28th European Photovoltaic Solar Energy Conference, Paris, France, 2013.

[21] I. Geisemeyer, C. Kallies, J. Hohl-Ebinger and W. Warta, «Contacting Bare Silicon Solar Cells with Advanced Cell Metallisation,» in Proceedings of 29th European Photovoltaic Solar Energy Conference, 
Amsterdam, The Netherlands, 2014.

[22] B. B. van Aken, E. E. Bende, M. W. Lamers, M. J. Goris and I. J. Bennett, «Cost, Efficiency and Material Optimisation of Back-contact Cell and Module Design,» Energy Procedia, vol. 55, pp. 34-379, 2014. 